\title{
EGCG Regulates Cell Apoptosis of Human Umbilical Vein Endothelial Cells Grown on 316L Stainless Steel for Stent Implantation
}

This article was published in the following Dove Press journal:

Drug Design, Development and Therapy

\author{
Jinpeng Wang $\mathbb{D}^{\prime}$ \\ Yue Wang ${ }^{2}$ \\ Yuyi Zhao ${ }^{2}$ \\ Jinbin Zhao ${ }^{2}$ \\ Beilin Zhang ${ }^{3}$ \\ Kun $\mathrm{Xu}^{2,4}$ \\ 'Department of Cardiology, The Second \\ Hospital of Jilin University, Changchun, \\ I3004I, People's Republic of China; \\ ${ }^{2}$ Department of Nutrition and Food \\ Hygiene, School of Public Health, Jilin \\ University, Changchun, I3002I, People's \\ Republic of China; ${ }^{3}$ Department of \\ Physiology, College of Basic Medical \\ Sciences, Jilin University, Changchun, \\ I3002 I, People's Republic of China; ${ }^{4}$ jilin \\ Engineering Research Center of Public \\ Health Detection, Changchun, I3002I, \\ People's Republic of China
}

Background: Nowadays, medical grade 316L stainless steel (316L SS) is being widely used for intravascular stents, and the drug-eluting stent (DES) system is able to significantly reduce the occurrences of in-stent restenosis. But the drugs and the polymer coating used in DES potentially induce the forming of late stent thrombosis. In order to reduce the occurrence of ISR after stent implantation, the development of novel drugs for DESs is urgently needed.

Methods: This study aimed to investigate the potential mechanisms of epigallocatechin3-gallate (EGCG) on human umbilical vein endothelial cells (HUVEC) grown on 316L stainless steel (316L SS) using flow cytometry and Q-PCR methods.

Results: Our results showed that EGCG $(12.5,25,50,100 \mu \mathrm{mol} / \mathrm{L})$ significantly inhibited HUVEC proliferation. Flow cytometry analysis indicated that EGCG $(25,50,100 \mu \mathrm{mol} / \mathrm{L})$ induced apoptosis. Moreover, qRT-PCRrevealed that genes associated with cell apoptosis (caspase-3, 8, 9, Fas) and autophagy (Atg 5, Atg 7, Atg 12) were up-regulated after EGCG treatment.

Conclusion: These findings indicate that EGCG possesses chemo preventive potential in stent coating which may serve as a novel new drug for stent implantation.

Keywords: EGCG, 316 stainless steel, HUVECs, apoptosis

\section{Introduction}

Coronary artery disease (CAD), commonly caused by atherosclerosis, is becoming one of the leading causes of mortality worldwide, especially in developed countries. The vascular stent is the most commonly used technique for the treatment of severe cases of CAD. However, restenosis and thrombosis are commonly occurring complications of this technique. In clinic, more than $20 \%$ of patients who received stent implantation developed in-stent restenosis (ISR). ${ }^{1}$ This phenomenon is only avoided when patients are treated with routine anticoagulation therapies. Thrombosis occurs due to insufficient re-endothelialization of the vascular stent surfaces after stent implantation. Nowadays, medical grade 316L stainless steel (316L SS) is being widely used for intravascular stents, due to its suitable mechanical properties and outstanding anticorrosion abilities. Meanwhile, immobilization of organic molecules on the surface of the metal is difficult due to the lack of surface reactive groups.

Drug-eluting stent (DES) system is an important milestone in the development of coronary intervention therapy, as the use of DES is able to significantly reduce the occurrences of ISR. ${ }^{2,3}$ Simultaneously, the drugs and the polymer coating used in DES

Correspondence: Kun Xu

Department of Nutrition and Food Hygiene, School of Public Health, Jilin University, Changchun, I3002I, People's Republic of China

Email xukun@jlu.edu.cn 
cause the delay of endothelialization and the healing process, which potentially induce the forming of late stent thrombosis (LST). ${ }^{4-6}$ Early neo-atherosclerosis observed with the newest DES designs was associated with the incidence of spontaneous myocardial infarction at late outcome. ${ }^{7}$ Additionally, there is evidence that DES designs also induce endothelial dysfunction that may be associated with long-term cardiac and non-cardiac adverse events, such as solid tumors. ${ }^{8}$

In order to reduce LST and anti-tumor after stent implantation, the development of novel drugs for DESs is urgently needed. Epigallocatechin-3-gallate (EGCG) is abundantly present in green tea and has been intensively studied for its biological and pharmacological effects, including anti-oxidation, anti-tumor, anti-infection, antiinflammation, and pro-apoptosis. ${ }^{9-16}$

In previous studies, EGCG treatments were demonstrated to inhibit proliferation and enhance apoptosis in cancer and other types of cell. ${ }^{17,18}$ EGCG has also been found to inhibit the proliferation of smooth muscle cells through the effects of $\mathrm{p} 53$ and NF- $\mathrm{BB}$ signaling pathways. ${ }^{19}$ Moreover, EGCG demonstrates protective effects during ischemia-reperfusion (I/R) injuries and apoptosis. Especially, EGCG has been found to have beneficial effects during $I / R$ injuries of the heart through the suppression of STAT1 phosphorylation. ${ }^{20}$ For those reasons, in this study, we aimed to investigate the potential effects of EGCG on modulating proliferation, apoptosis, and related signaling pathways of human umbilical vein endothelial cells (HUVECs) on 316L SS.

In this study, we provided novel evidence of the effects and intracellular mechanisms of EGCG on the proliferation of HUVECs through 316L SS co-

culturing and investigated the potential application of EGCG as an inhibitory drug on the coating of DES to reduce the occurrence of ISR.

\section{Materials and Methods}

\section{Materials}

316L SS materials (C: 0.025; Cr: 17.5; Mn: 1.06; Mo: 2.66; Ni: 13.07; Si: 0.6; S: 0.008; P: $0.02 \mathrm{wt} \%$ and Fe in balance) were machined into $\Phi 32 \times 1 \mathrm{~mm}$. All materials were merged in $75 \%$ ethanol and ultrasonically cleaned, rinsed with sterile water, and disinfected at $121^{\circ} \mathrm{C}$ for $20 \mathrm{~min}$.

\section{Groups}

HUVECs cultured on the surface of 316L SS were divided into five groups: $316 \mathrm{~L}$ group (without EGCG); 316L+EGCG
$(12.5 \mu \mathrm{mol} / \mathrm{L}) ; 316 \mathrm{~L}+\mathrm{EGCG}(25 \mu \mathrm{mol} / \mathrm{L}) ; 316 \mathrm{~L}+\mathrm{EGCG}$ $(50 \mu \mathrm{mol} / \mathrm{L}) ; 316 \mathrm{~L}+\mathrm{EGCG}(100 \mu \mathrm{mol} / \mathrm{L})$. Untreated cells cultured without $316 \mathrm{~L}$ SS were used as the control group.

\section{Cell Culture}

HUVECs were purchased from KeyGen biotech company (No: KG330, KeyGen, Jiangsu, China) and cultured with DMEM (Hyclone, China) with 10\% fetal bovine serum (FBS) (Gibco, USA), penicillin (100 IU/mL), and streptomycin $(100 \mu \mathrm{g} / \mathrm{mL})$ in a cell incubator $\left(\mathrm{CO}_{2}, 5 \%\right)$ at $37^{\circ} \mathrm{C}$.

\section{Cell Adhesion}

HUVECs $\left(5 \times 10^{5}\right.$ cells $\left./ \mathrm{mL}\right)$ were plated on $316 \mathrm{~L}$ SS in 6-well cell plates (Thermo Fisher Scientific, USA), and incubated for $4 \mathrm{~h}$. The 316L SS plates were carefully rinsed with cell medium and then washed with phosphatebuffered saline (PBS) buffer X2. Adhered cells were digested with $0.25 \%$ trypsin (Gibco, USA), and counted using trypan blue under a microscope.

\section{Observation of Cell Morphology}

HUVECs $(20,000$ cells $/ \mathrm{mL})$ were labeled with calcein AM (dissolved in ethanol, dye for living cells), plated in 6-well cell plates (without or with the EGCG treatments at 12.5, $25,50,100 \mu \mathrm{m} / \mathrm{L}$ ), and incubated for 3 days. The viabilities of HUVECs were evaluated by fluorescence microscopy (Olympus IX81, Japan).

\section{Apoptosis Assessment by Flow Cytometry}

HUVECs $(5000$ cells $/ \mathrm{mL})$ were plated on $316 \mathrm{~L}$ SS and cultured for 7 days. Cells were freshly harvested, washed with PBS buffer X2, and resuspended with AnnexinVFITC and PI (Beyotime Biotechnology, China) buffer for $15 \mathrm{~min}$ at room temperature (avoiding light). In flow cytometry, apoptotic cells were marked with Annexin V +/PI- (early apoptotic) or Annexin V+/PI+ (late apoptotic). Annexin-V can bind to phosphatidylserine which is everted on the cell surface in the presence of calcium ion, and eversion of phosphatidylserine is an early stage of apoptosis.

PI is a kind of DNA dye. In the late stage of apoptosis, the permeability of the cell membrane increases, PI enters the nucleus and binds to DNA. Flowjo software (Becton, Dickinson and Company, USA) was used for the analysis. 
Table I The Primer Sequence of Target Gene

\begin{tabular}{|c|c|c|}
\hline Gene & & Sequence $\left(5^{\prime}-3^{\prime}\right)$ \\
\hline GAPDH & $\begin{array}{l}\text { Forward } \\
\text { Reverse }\end{array}$ & $\begin{array}{l}\text { GCACCGTCAAGGCTGAGAAC } \\
\text { TGGTGAAGACGCCAGTGGA }\end{array}$ \\
\hline Caspase3 & $\begin{array}{l}\text { Forward } \\
\text { Reverse }\end{array}$ & $\begin{array}{l}\text { GACTCTGGAATATCCCTGGACAACA } \\
\text { AGGTTTGCTGCATCGACATCTG }\end{array}$ \\
\hline Caspase8 & $\begin{array}{l}\text { Forward } \\
\text { Reverse }\end{array}$ & $\begin{array}{l}\text { CATTTGCATATTTAGCCGCCAAG } \\
\text { TTAAGAGTCCCAGGAATTCAGCAAC }\end{array}$ \\
\hline Caspase9 & $\begin{array}{l}\text { Forward } \\
\text { Reverse }\end{array}$ & $\begin{array}{l}\text { GCCATATCTAGTTTGCCCACACC } \\
\text { CACTGCTCAAAGATGTCGTCCA }\end{array}$ \\
\hline Fas & $\begin{array}{l}\text { Forward } \\
\text { Reverse }\end{array}$ & $\begin{array}{l}\text { CAACAACCATGCTGGGCATC } \\
\text { TGATGTCAGTCACTTGGGCATTA AC }\end{array}$ \\
\hline $\operatorname{Atg} 5$ & $\begin{array}{l}\text { Forward } \\
\text { Reverse }\end{array}$ & $\begin{array}{l}\text { TTGA ATATGAAGGCACACCACTGAA } \\
\text { GCATCCTTAGATGGACAGTGCAGA }\end{array}$ \\
\hline Atg7 & $\begin{array}{l}\text { Forward } \\
\text { Reverse }\end{array}$ & $\begin{array}{l}\text { CTGTAACTTAGCCCAGTACCCTGGA } \\
\text { TACGGTCACGGAAGCAAACAAC }\end{array}$ \\
\hline Atg 12 & $\begin{array}{l}\text { Forward } \\
\text { Reverse }\end{array}$ & $\begin{array}{l}\text { AGTAGAGCGAACACGAACCATCC } \\
\text { CCACGCCTGAGACTTGCAGTA }\end{array}$ \\
\hline
\end{tabular}

\section{Quantitative Real-Time PCR}

HUVECs $(5000$ cells $/ \mathrm{mL})$ were plated on 316L SS and cultured for 7 days. Total RNA was harvested by TRIzol reagent (Invitrogen, USA) and reversetranscription was used to obtain cDNA by using reverse transcription (RT) reagents (Takara Biotechnology Co., Ltd., China). Target sequences were amplified by quantitative real-time PCR (qRTPCR) using SYBR Premix Ex Taq II (Takara Biotechnology Co., Ltd., China) on a Real-Time PCR system (ABI prism 7500, Applied Biosystems, Foster City, USA) platform. Primers for qRT-PCR are listed in Table 1. All data were analyzed based on $-\Delta \Delta \mathrm{Ct}$ method. GAPDH was used as the internal control.

\section{Statistical Analysis}

Data analysis was carried out by SPSS software (Chicago, USA). All data were displayed as means \pm standard deviation (SD) $(n=3)$. One-way analysis of variance (ANOVA) followed by least significant difference (LSD) was used for statistical analysis. Rank sum test was used for nonparametric analysis. $\mathrm{P}$ value $<0.05$ was considered as statistically significant.

\section{Result}

\section{Effect of EGCG on HUVECs on 316L SS Surface}

As shown in Figure 1, the proliferation of HUVECs on the 316L SS surface was observed. As a result, HUVECs were distributed as monolayers with no significant difference in cell morphology observed between cells on 316L SS and control. Living cell numbers in both the 316L SS group and EGCG treated group were elevated with time. Densities of HUVECs on 316 L SS surface were observed as the highest compared with both control and EGCG treated groups.

\section{Effect of EGCG on Apoptosis of HUVECs Co-Cultured with 316L SS}

Flow cytometry was carried out for the assessment of the effects of EGCG on the apoptosis of HUVECs on 316L SS. (Figure 2). Early apoptotic ratio of HUVECs was $6.79 \%$ for the $316 \mathrm{~L}$ group, which was lower than that of the control group (9.16\%). Meanwhile, the apoptotic ratios of the early apoptotic HUVECs were $8.4 \%, 8.15 \%$, $12.57 \%$, and $34.74 \%$ for EGCG treatments of $12.5,25$, 50 , and $100 \mu \mathrm{mol} / \mathrm{L}$, respectively. Later apoptotic ratio of HUVECs was $1.79 \%$ for the $316 \mathrm{~L}$ group, which was lower than that of the control group $(2.58 \%)$. Later apoptotic ratios of HUVECs were $3.92 \%, 2.62 \%, 4.89 \%$, and $9.85 \%$ for EGCG treatments of $12.5,25,50$, and 100 $\mu \mathrm{mol} / \mathrm{L}$, respectively.

\section{Effect of EGCG on Apoptotic Genes of HUVECs Co-Cultured with 3I6L SS}

The mitochondrial pathway, featured by the activation of caspase-9, is closely related to the regulations of apoptosis. ${ }^{21}$ The relative mRNA expressions of Caspase3 and Caspase- 9 in the EGCG $(25,50,100 \mu \mathrm{m} / \mathrm{L})$ treated group were increased compared with the $316 \mathrm{~L}$ group. The relative mRNA expressions of Caspase- 8 and Fas in the EGCG $(12.5,25,50,100 \mu \mathrm{m} / \mathrm{L})$ group were also increased compared with the $316 \mathrm{~L}$ group (Figure $3 \mathrm{~A}$ ).

\section{Effect of EGCG on Autophagy of HUVECs Co-Cultured with 316L SS}

The qRT-PCR analysis demonstrated that the expressions of regulator genes of autophagy: ATG5, ATG7, and ATG12, were increased in HUVECs on the 316L SS 


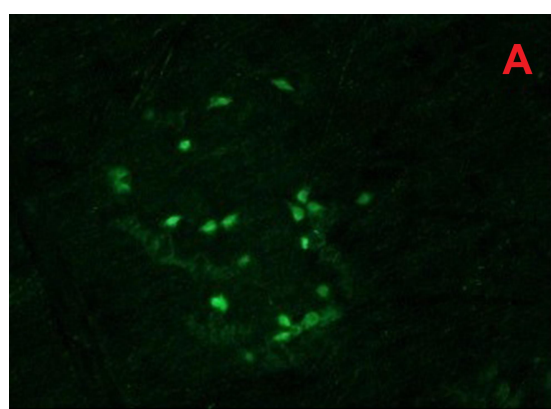

Control

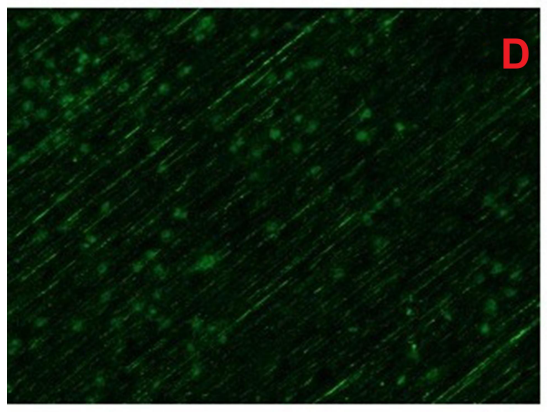

$\mathrm{EGCG} 25 \mu \mathrm{mol} / \mathrm{L}+316 \mathrm{~L}$

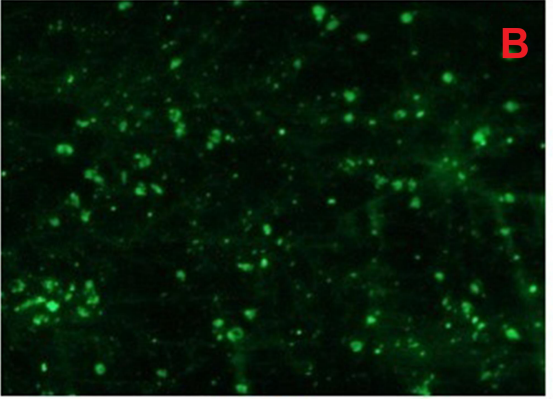

$316 L$

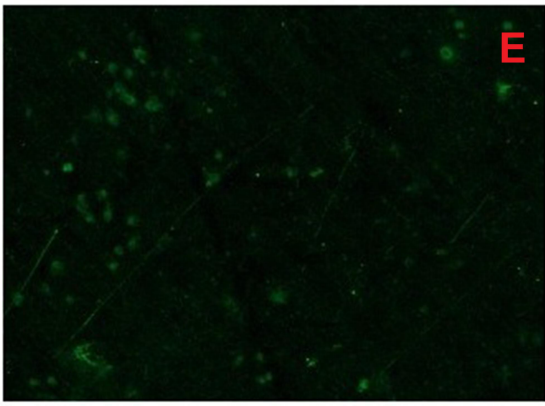

EGCG50 $\mu \mathrm{mol} / \mathrm{L}+316 \mathrm{~L}$



EGCG12.5 $\mu \mathrm{mol} / \mathrm{L}+316 \mathrm{~L}$

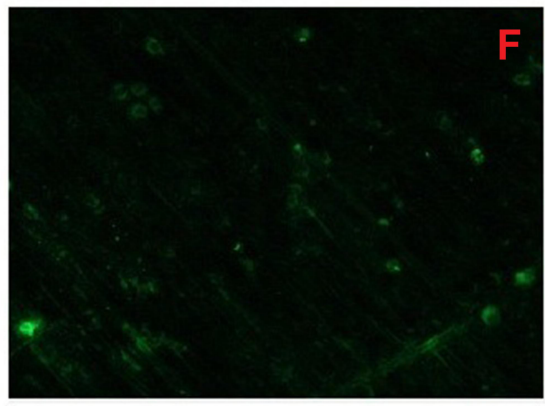

EGCG100 $\mu \mathrm{mol} / \mathrm{L}+316 \mathrm{~L}$

Figure I Fluorescent images of HUVECs grown on $316 \mathrm{~L}$ surface. Cultured for 3 days $(* 40)$. (A) Control (B) $316 \mathrm{~L}$ (C) $316 \mathrm{~L}+12.5 \mu \mathrm{mol} / \mathrm{L},($ D), $316 \mathrm{~L}+25 \mu \mathrm{mol} / \mathrm{L}$ (E) $316 \mathrm{~L}$ $+50 \mu \mathrm{mol} / \mathrm{L}$, and (F) $316 \mathrm{~L}+100 \mu \mathrm{mol} / \mathrm{L}$.

surface, indicating the activation of autophagy. Moreover, EGCG $(25,50,100 \mu \mathrm{mol} / \mathrm{L})$ enhanced the expression of ATG5, ATG7, and ATG12 in HUVECS co-cultured with 316L SS (Figure 3B).

\section{Discussion}

Our results showed that EGCG $(12.5,25,50,100 \mu \mathrm{mol} / \mathrm{L})$ significantly inhibited HUVEC proliferation. Flow cytometry analysis indicated that EGCG $(25,50,100 \mu \mathrm{mol} / \mathrm{L})$ induced apoptosis. Moreover, as revealed by qRT-PCR, we found that the expressions of genes associated with cell apoptosis (caspase 3, caspase 8, caspase 9 and Fas) and autophagy (Atg 5, Atg 7, Atg 12) were up-regulated after EGCG treatments.

Vascular stent implantation is a widely acknowledged method for the clinical treatment of arterial trauma. However, the naked surface of the metallic stent also potentially acts as a stimulus promoting allergies and inflammation. A large number of epidemiological studies have suggested that green tea can exert an anti-cancer effect on a variety of tumor cells, and long-term consumption of green tea reduces the risks of various cancers. EGCG enhances autophagy through the promotion of autophagosome formation, the enhancement of lysosomal acidification, and the stimulation of autophagic flux in Müller cells. ${ }^{22} \mathrm{Li}$ et al demonstrated that HUVECs exposed to 316L SS could cause cell proliferation compared with the medium group. ${ }^{23}$ In this study, our cell morphology results showed higher living cell numbers of HUVECs on the 316L SS surface than in the controls. Furthermore, the treatments with EGCG $(12.5,25,50,100$ $\mu \mathrm{m} / \mathrm{L}$ ) significantly reduced the number of HUVECs on 316L SS surface. Our results were consistent with the findings of Zhang et al, where EGCG treatments were demonstrated to inhibit cell proliferation during $I / R$ injuries. $^{24}$

To investigate the underlying mechanisms of the inhibitory effects of EGCG treatments on cell proliferation on 316L SS surface, flow cytometry analysis was performed. In the results of flow cytometry, it was shown that EGCG $(25,50,100 \mu \mathrm{mol} / \mathrm{L})$ treatments promoted the apoptosis of HUVECs compared with the $316 \mathrm{~L}$ group. Apoptosis is mainly induced through two approaches. One of them is through the activation of caspase by extracellular stimulus and the Fas-dependent pathway. Fas belongs to the transmembrane protein of the tumor necrosis factor receptor superfamily. Fas is able to bind with its ligand FasL and initiate signal transductions, which activate caspase- 8 and 

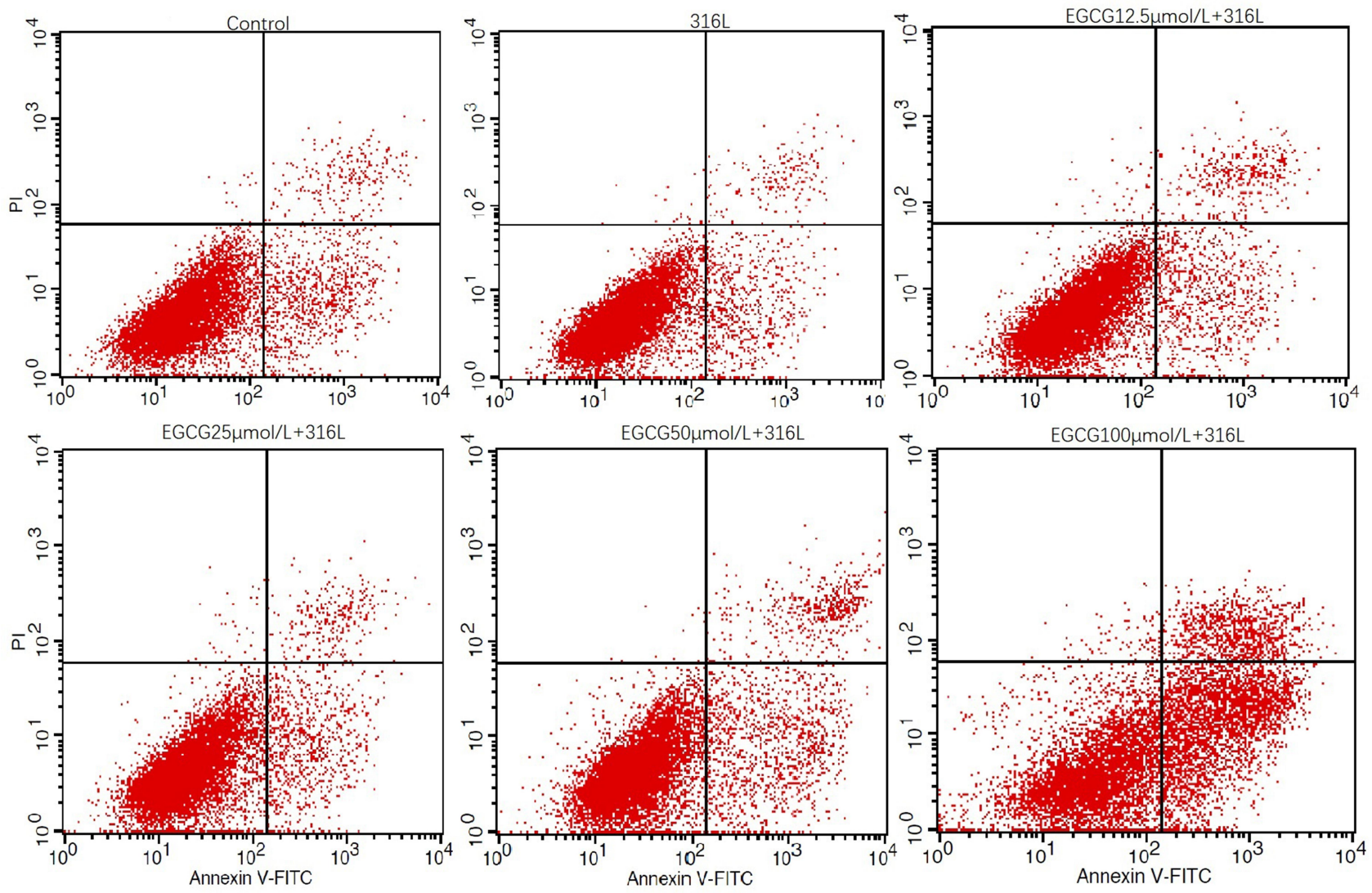

Figure 2 Flow cytometry analysis of apoptosis of HUVECs. Cells were cultured on $316 \mathrm{~L}$ SS surface without or with EGCG treatments (I2.5, 25,50 , I00 $\mu$ mol/L) for 3 days. Annexin-V positive PI negative represents the proportion of early apoptotic cells; quadrant of early apoptotic stage was in right lower quadrant. Annexin-V positive PIpositive cells represent the late apoptotic or necrotic cells. Quadrant of late apoptotic cells was in the right upper quadrant.

the signaling cascades, which subsequently leads to the induction of apoptosis. Another approach for apoptosis induction is through the release of apoptosis protease activating factor (Apaf) by mitochondria, which leads to the activation of caspase. Stimulations such as stress and apoptotic signals cause the release of cytochrome $\mathrm{C}$ by cells. With the existence of dATP, extracellular cytochrome $\mathrm{C}$ forms polymers with Apaf-1, and enhances the formation of apoptotic bodies with caspase-9. Subsequently, caspase- 9 is activated. Its activation also induces the activations of other caspases such as caspase3 , and thus causes the apoptosis of cells. ${ }^{25,26}$ Autophagy happens during conditions such as nutrient deprivation and stress responses, in order to promote the survival of cells. Four autophagy-related genes were discovered in the studies of yeast, and have been proven to play critical roles in
A



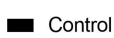

$\square 316 \mathrm{~L}$

$316 \mathrm{~L}+12.5 \mu \mathrm{mol} / \mathrm{L}$ EGCG

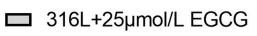

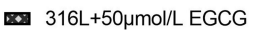

ab $316 \mathrm{~L}+100 \mu \mathrm{mol} / \mathrm{L}$ EGCG
B

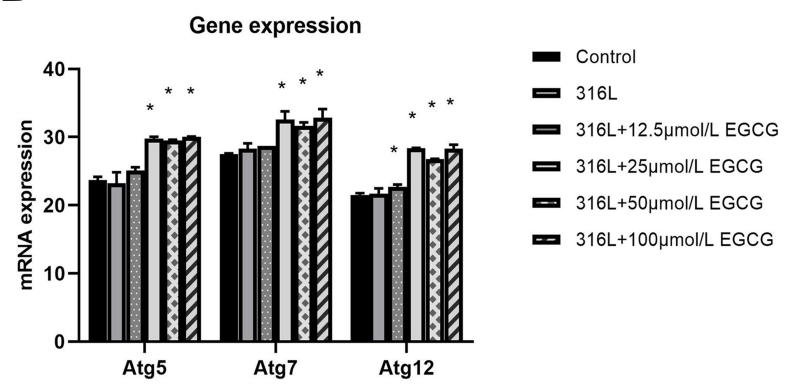

Figure 3 Gene expression profiles of HUVECs. (A) Shows apoptotic genes and (B) shows autophagic genes. Data were displayed as mean \pm SD. $* P<0.05$ compared with $316 \mathrm{~L}$ group. 
the induction, processing, maturation, and recycling of autophagy. Atg5 is widely accepted as a key component in the mechanisms of autophagy. Atg 5 contributes to the process of ubiquitin-like conjugation system, which is indispensable during the pre-autophagosomal structure elongation process. Atg12 is an ubiquitin-like protein, able to bind with Atg5 through covalent bonds, under the facilitation of Atg7 and Atg10. This Atg12-Atg5 heterodimer subsequently binds with Atg16Land forms a multiprotein complex. ${ }^{27}$ Meanwhile, autophagy and apoptosis are closely associated processes rather than isolated. Caspase- 8 has been found to participate in the regulation of autophagy, while Atg5 has also been found to interact with Fas-associating protein with a novel death domain (FADD) and induce apoptosis. ${ }^{28,29}$ In this study, we found that 7 days after the EGCG treatments (except for low dose treatment at $12.5 \mathrm{~mol} / \mathrm{L}$ ), the expressions of caspase- 3 were found to be higher than that in the $316 \mathrm{~L} \mathrm{SS}$ group. Meanwhile, as revealed by higher expression levels of caspase-8, caspase-9, Atg 5, Atg7, and Atg12, EGCG treatments (at all treatment doses) were demonstrated to inhibit the proliferation of cells on 316L SS surface through the promotion of both autophagy and apoptosis.

However, the mechanisms involved in $316 \mathrm{~L}$ material for the growth of HUVECs are complex, as is the function of EGCG; therefore, further research is required.

\section{Conclusion}

In this study, we demonstrated the effects of EGCG on HUVECs' growth on 316L SS surface. EGCG $(12.5,25$, 50, $100 \mu \mathrm{mol} / \mathrm{L})$ significantly inhibited HUVEC cell proliferation. As revealed by flow cytometry, EGCG promoted the apoptosis of cells growing on 316L SS surface. The gene expression profile of HUVECs was analyzed by qRT-PCR and indicated promoted cell apoptosis and autophagy caused by EGCG treatment, as revealed by higher gene expression levels of genes related to both apoptosis and autophagy. Our results provided robust evidence suggesting that EGCG promoted the apoptosis of endothelial cells through the regulation of apoptotic and autophagic genes. These results and conclusions established solid foundations for the new drug development of stent applications. However, further in vivo studies for the validation of our conclusions are necessary.

\section{Acknowledgment}

This work was financially supported by the Jilin Province Development and Reform Commission (grant number: 2020C038-7), the Development of Science and Technology, Jilin Province, China (grant number: 2018010195JC), National Natural Science Foundation of China (grant number: 81401721), the Education Department of Jilin Province, China (grant number: JJKH20180239KJ), and the Health and Family Planning Commission of Jilin Province (grant number: 2017J074). There is no conflict to declare regarding funding.

\section{Disclosure}

We declare that there are no financial or other contractual agreements that may cause conflicts of interest or be perceived as causing conflicts of interest.

\section{References}

1. Bauters C, Banos J-L, Van Belle E, et al. Six-month angiographic outcome after successful repeat percutaneous intervention for in-stent restenosis. Circulation. 1998;97(4):318-321. doi:10.1161/01. CIR.97.4.318

2. Zilberman M, Eberhart RC. Drug-eluting bioresorbable stents for various applications. Annu Rev Biomed Eng. 2006;8:153-180. doi:10.1146/annurev.bioeng.8.013106.151418

3. Eisenberg MJ, Konnyu KJ. Review of randomized clinical trials of drug-eluting stents for the prevention of in-stent restenosis. $\mathrm{Am}$ $J$ Cardiol. 2006;98:375-382. doi:10.1016/j.amjcard.2006.02.042

4. Martin DM, Boyle FJ. Drug-eluting stents for coronary artery disease: a review. Med Eng Phys. 2011;33:148-163. doi:10.1016/j. medengphy.2010.10.009

5. Kaneko H, Kijima M. Role of bare-metal stents for left main coronary artery disease in the era of drug-eluting stents -which coronary stent should be used for left main trunk disease? BMS or DES? (BMS-side)-. Circ J. 2011;75:1243-1249. doi:10.1253/circj.CJ-11-0234

6. Siddiqi OK, Faxon DP. Very late stent thrombosis: current concepts. Curr Opin Cardiol. 2012;27:634-641. doi:10.1097/ HCO.0b013e3283587c7e

7. Toya T, Sara JD, Corban MT, et al. Assessment of peripheral endothelial function predicts future risk of solid-tumor cancer. Eur J Prev Cardiol. 2020;27:608-618. doi:10.1177/2047487319884246

8. Rodriguez AE, Rodríguez AE, Fernández-Pereira C, AscarrunzCattoretti D. Increased incidence of serious late adverse events with drug-eluting stents when compared with coronary artery bypass surgery: a cause of concern. Future Cardiol. 2020;16:711-723. doi:10.2217/fca-2020-0033

9. Byun JK, Yoon BY, Jhun JY, et al. Epigallocatechin-3-gallate ameliorates both obesity and autoinflammatory arthritis aggravated by obesity by altering the balance among CD4+ T-cell subsets. Immunol Lett. 2014;157:51-59. doi:10.1016/j.imlet.2013.11.006

10. Fiorini RN, Donovan JL, Rodwell D, et al. Short-term administration of (-)-epigallocatechin gallate reduces hepatic steatosis and protects against warm hepatic ischemia/reperfusion injury in steatotic mice. Liver Transpl. 2005;11(3):298-308. doi:10.1002/lt.20348

11. Jamal MH, Ali H, Dashti A, et al. Effect of epigallocatechin gallate on uncoupling protein 2 in acute liver injury. Int J Clin Exp Pathol. 2015;8:649-654. 
12. Pang JY, Zhao KJ, Wang JB, Ma ZJ, Xiao XH. Green tea polyphenol, epigallocatechin-3-gallate, possesses the antiviral activity necessary to fight against the hepatitis B virus replication in vitro. $J$ Zhejiang Univ Sci B. 2014;15:533-539. doi:10.1631/jzus.B1300307

13. Singh BN, Shankar S, Srivastava RK. Green tea catechin, epigallocatechin-3-gallate (EGCG): mechanisms, perspectives and clinical applications. Biochem Pharmacol. 2011;82:1807-1821. doi:10.1016/j.bcp.2011.07.093

14. Tipoe GL, Leung TM, Liong EC, Lau TYH, Fung ML, Nanji AA. Epigallocatechin-3-gallate (EGCG) reduces liver inflammation, oxidative stress and fibrosis in carbon tetrachloride (CCl4)-induced liver injury in mice. Toxicology. 2010;273:45-52. doi:10.1016/j.tox.2010.04.014

15. Wu D, Wang J, Pae M, Meydani SN. Green tea EGCG, T cells, and T cell-mediated autoimmune diseases. Mol Aspects Med. 2012;33:107-118. doi:10.1016/j.mam.2011.10.001

16. Chen L, Zhang HY. Cancer preventive mechanisms of the green tea polyphenol (-)-epigallocatechin-3-gallate. Molecules. 2007;12:946-957. doi:10.3390/12050946

17. Park G, Yoon BS, Moon JH, et al. Green tea polyphenol epigallocatechin-3-gallate suppresses collagen production and proliferation in keloid fibroblasts via inhibition of the STAT3-signaling pathway. J Invest Dermatol. 2008;128:29-2441. doi:10.1038/jid.2008.103

18. Sah JF, Balasubramanian S, Eckert RL, Rorke EA. Epigallocatechin3-gallate inhibits epidermal growth factor receptor signaling pathway, evidence for direct inhibition of ERK1/2 and AKT kinases. $J$ Biol Chem. 2004;279(13):12755-12762. doi:10.1074/jbc.M312333200

19. Hofmann CS, Sonenshein GE. Green tea polyphenol epigallocatechin-3 gallate induces apoptosis of proliferating vascular smooth muscle cells via activation of p53. FASEB J. 2003;17 (6):702-704. doi:10.1096/fj.02-0665fje

20. Townsend PA, Scarabelli TM, Pasini E, et al. Epigallocatechin-3-gallate inhibits STAT-1 activation and protects cardiac myocytes from ischemia/ reperfusion-induced apoptosis. FASEB J. 2004;18:1621-1623. doi:10.1096/fj.04-1716fje
21. Yang F, Wu W, Cao L, et al. Pathways of macrophage apoptosis within the interface membrane in aseptic loosening of prostheses. Biomaterials. 2011;32:9159-9167. doi:10.1016/j.biomaterials.2011. 08.039

22. Wang L, Sun XD, Zhu MH, et al. Epigallocatechin-3-gallate stimulates autophagy and reduces apoptosis levels in retinal müller cells under high-glucose conditions. Exp Cell Res. 2019;380(2):149-158. doi:10.1016/j.yexcr.2019.04.014

23. Li L, Pan S, Zhou XH, et al. Reduction of in-stent restenosis risk on nickel-free stainless steel by regulating cell apoptosis and cell cycle. PLoS One. 2013;8(4):e62193. doi:10.1371/journal.pone.0062193

24. Zhang T, Yang D, Fan Y, Xie P, Li HH. Epigallocatechin-3-gallate enhances ischemia/reperfusion-induced apoptosis in human umbilical vein endothelial cells via AKT and MAPK pathways. Apoptosis. 2009;14(10):1245-1254. doi:10.1007/s10495-009-0391-1

25. Chen Y, Klionsky DJ. The regulation of autophagy unanswered questions. J Cell Sci. 2011;124:161-170. doi:10.1242/jcs.064576

26. Thorbum A. Apoptosis and autophagy: regulatory connections between two supposedly different processes. Apoptosis. 2007;13:1-9. doi:10.1007/s10495-007-0154-9

27. Eisenberg-Lerner A, Bialik S, Simon HU, Kimchi A. Life and death partners: apoptosis, autophagy and the cross-talk between them. Cell Death Differ. 2009;16:966-975. doi:10.1038/cdd.2009.33

28. Pyo JO, Jang MH, Kwon YK, et al. Essential roles of At95 and FADD in autophagic cell death: dissection of autophagic cell death into vacuole formation and cell death. $J$ Biol Chem. 2005;280:20722-20729. doi:10.1074/jbc.M413934200

29. Hoesel B, Schmid JA. The complexity of NF-kappaB signaling in inflammation and cancer. Mol Cancer. 2013;12:86. doi:10.1186/ 1476-4598-12-86
Drug Design, Development and Therapy

\section{Publish your work in this journal}

Drug Design, Development and Therapy is an international, peerreviewed open-access journal that spans the spectrum of drug design and development through to clinical applications. Clinical outcomes, patient safety, and programs for the development and effective, safe, and sustained use of medicines are a feature of the journal, which has also

\section{Dovepress}

been accepted for indexing on PubMed Central. The manuscript management system is completely online and includes a very quick and fair peer-review system, which is all easy to use. Visit http://www. dovepress.com/testimonials.php to read real quotes from published authors. 